\title{
Spatial and Temporal Genetic Homogeneity of Orf Viruses Infecting Japanese Serows (Capricornis crispus)
}

\author{
Yasuo INOSHIMA ${ }^{1) *}$, Mika ITO ${ }^{2)}$ and Naotaka ISHIGURO ${ }^{1)}$ \\ ${ }^{1)}$ Laboratory of Food and Environmental Hygiene, Department of Veterinary Medicine, Gifu University, 1-1 Yanagido, Gifu 501-1193 and \\ ${ }^{2)}$ Nanbu Livestock Hygiene Service Center, 324-2 Bo, Saida-machi, Kanazawa, Ishikawa 920-3101, Japan
}

(Received 19 October 2009/Accepted 19 January 2010/Published online in J-STAGE 2 February 2010)

\begin{abstract}
This study genetically characterized orf viruses (ORFVs) isolated from recent outbreaks in Japanese serows (Capricornis crispus) in 2007 and 2008, and from earlier outbreaks from 1985 to 2001. Nucleotide sequences of genes for the viral envelope, vascular endothelial growth factor (VEGF), and virus interferon resistance (VIR) were determined in two ORFVs isolated from recent outbreaks and in eight from earlier outbreaks. No deletions or insertions were observed in these genes. Surprisingly, the amino acid sequences of the envelope and VIR genes were identical among the 10 ORFVs, and only one amino acid substitution in the VEGF gene was found in one of the two recent ORFVs (2007). Genotyping by differential PCR for the A32L gene, which encodes an ATPase, classified all of the 10 ORFVs into the same genotype. In an ORFV isolated from a sheep in 1970, the three sequenced genes were almost the same as in the ORFVs isolated from Japanese serows, and the ORFV in 1970 was classified into the same genotype as the ORFVs from Japanese serows. These results suggest that recent outbreaks in Japanese serows are caused by ORFVs genetically closely related to the viruses in earlier outbreaks and that these genetically stable ORFVs have circulated among Japanese serows over a long period of time. KEY WORDS: contagious pustular dermatitis, Japanese serow, orf virus, outbreak, sequence.
\end{abstract}

J. Vet. Med. Sci. 72(6): 701-707, 2010

Parapoxviruses (PPVs) cause papular stomatitis and pseudocowpox in cattle and contagious pustular dermatitis in sheep and goats $[8,33]$. PPV infections in Japan were reported in cattle in the 1960s [32], in sheep in the 1940s [2] and in wild Japanese serows (Capricornis crispus) in the 1970s [26]. Serological surveys have demonstrated that $72.0 \%$ of cattle $(1,310 / 1,819)$ from various regions of Japan were seropositive for PPV, ranging from 40.0 to $98.0 \%$ in 1998 [36] and that $88.5 \%$ of sheep in Hokkaido were seropositive [27]. Seroprevalence among Japanese serows was previously reported to be $24.0 \%$ (40/167 from 1984 to 1999$)$ $[20,21]$. These findings indicate that healthy cattle and sheep can be infected subclinically with PPV and that the infection is widespread among both domestic and wild ruminants in Japan.

Recently, PPV epidemics have been frequently observed in wild Japanese serows in central Japan. Epidemics have occurred in these areas since December 1984, and 155 of 402 serows (39.6\%) captured from December 1984 to March 1985 were clinically affected [40]. Tikkanen et al. reported that a recent outbreak of PPV infection in Finnish reindeer (Rangifer tarandus tarandus; 1999 to 2000) was caused by pseudocowpox virus, a species of the genus Parapoxvirus, whereas an earlier outbreak (1992 to 1994) was caused by orf virus (ORFV), a prototype species of PPV [42]. Sequence analyses of the viral envelope gene indicate that contagious pustular dermatitis in Japanese serows is mainly caused by ORFV $[18,19]$. However, only a partial sequence of the envelope gene was analyzed in these stud-

\footnotetext{
* Correspondence to: Inoshima, Y., Laboratory of Food and Environmental Hygiene, Department of Veterinary Medicine, Gifu University, 1-1 Yanagido, Gifu 501-1193, Japan.

e-mail: inoshima@gifu-u.ac.jp
}

ies, and in other countries, sequence variations occur in the envelope gene of ORFVs isolated from the same outbreaks $[1,5,6,12,14,24]$. In general, the amino acid sequences of the genes encoding viral structural proteins, such as the envelope, are relatively well conserved, but the detailed genetic relationship between the PPVs of the recent and earlier outbreaks in Japanese serows is unclear. To assess genetic heterogeneity among PPVs in Japanese serows, it is necessary to analyze other genes, especially genes encoding non-structural proteins.

In this study, we analyzed nucleotide sequences of three viral genes that encode both structural and non-structural proteins, namely, the viral envelope, vascular endothelial growth factor (VEGF) and virus interferon resistance (VIR) genes. The VEGF and VIR genes are thought to be among the several virulence or immune modulator genes [13]. We also genotyped PPVs isolated from recent and earlier outbreaks in Japanese serows using differential PCR for the A32L gene [4], which encodes an ATPase and is involved in DNA packaging [9, 30].

\section{MATERIALS AND METHODS}

Viruses and cells: Two PPVs from recent outbreaks in Japanese serows (2007 and 2008) and eight PPVs from earlier outbreaks (1985 to 2001) were used in this study. We used both isolated PPVs and lesions of affected animals for genetic analyses because virus isolation is sometimes unsuccessful even though virus-like particles are observed in the lesions and it is also possible that a genetically minor virus can be selected and propagated in cell culture and isolated. Three ORFVs from sheep in Japan were also used for comparison. The virus source locations are shown in Fig. 1, 


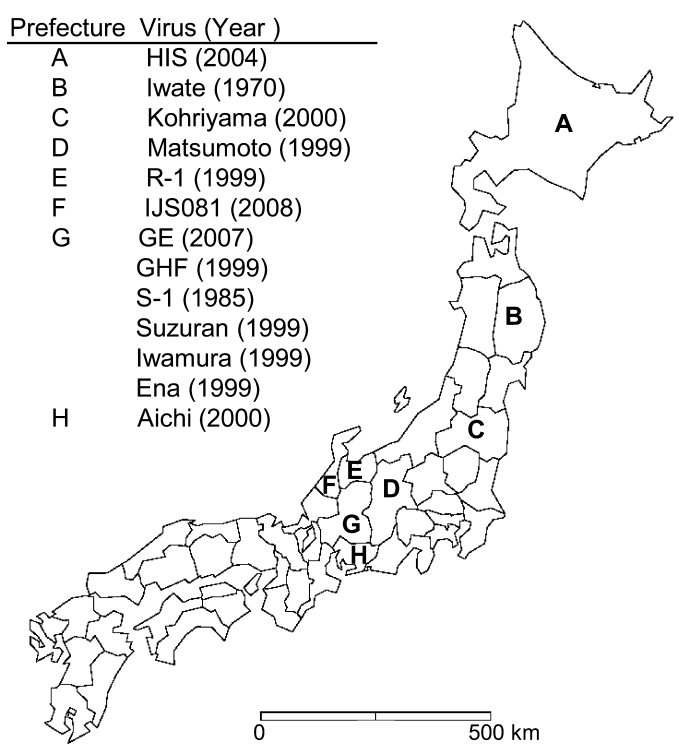

Fig. 1. Source locations of PPVs from Japanese serows and sheep. The year of isolation or collection is also listed. (A) Hokkaido, (B) Iwate, (C) Fukushima, (D) Nagano, (E) Toyama, (F) Ishikawa, (G) Gifu and (H) Aichi Prefectures.

and other information, including sequence accession numbers, is shown in Table 1. The GE (Gifu Ena) strain was newly isolated in this study from scab lesions around the mouth of an affected Japanese serow in 2007 and was passaged twice in primary fetal lamb lung cells. The IJS081 strain was isolated from lesions of the lips of an affected Japanese serow in 2008 [22]. These two strains were used as PPVs from recent outbreaks. All PPVs were propagated in primary fetal bovine muscle cells. Cells were maintained in Eagle's minimum essential medium (MEM, Nissui,
Tokyo, Japan) supplemented with $0.3 \%$ tryptose phosphate broth (Difco, Detroit, MI, U.S.A.), 10\% fetal bovine serum and $60 \mathrm{mg} / \mathrm{l} \mathrm{kanamycin}$.

DNA extraction: DNA was extracted from virus-infected cells or directly from lesions using a DNeasy Blood and Tissue Kit (Qiagen, Hilden, Germany) according to the manufacturer's instructions.

Polymerase chain reaction (PCR) and sequencing: The primers used for PCR and sequencing are shown in Table 2. PCR conditions for envelope, VEGF and VIR were as follows. The PCR reaction mixture $(50 \mu l)$ contained $0.2 \mu \mathrm{M}$ each of primer, $800 \mu \mathrm{M}$ dNTP mix, $10 \mathrm{mM}$ Tris- $\mathrm{HCl}(\mathrm{pH}$ 8.3), $50 \mathrm{mM} \mathrm{KCl}, 1.5 \mathrm{mM} \mathrm{MgCl} 2,1 \mathrm{U}$ AmpliTaq Gold DNA polymerase (Applied Biosystems, Foster City, CA, U.S.A.) and $1 \mu l$ extracted DNA. PCR consisted of 9 min at $95^{\circ} \mathrm{C}$ followed by 35 cycles at $94^{\circ} \mathrm{C}$ for $30 \mathrm{sec}, 55^{\circ} \mathrm{C}$ for 30 $\sec \left(40^{\circ} \mathrm{C}\right.$ for VEGF) and $72^{\circ} \mathrm{C}$ for $30 \mathrm{sec}$, with a final extension at $72^{\circ} \mathrm{C}$ for $7 \mathrm{~min}$. For sequencing, the PCR products were purified using a QIAquick PCR Purification Kit (Qiagen), and nucleotide sequences were determined by direct sequencing using an ABI 310 DNA sequencer with a BigDye Terminator Cycle Sequencing Kit (Applied Biosystems). For verification, sequencing was performed in both directions.

The genotyping of ORFVs by differential PCR for the A32L gene, based on variations and deletions in the sequence, was recently described by Chan et al. [4]. The PCR conditions for A32L were as follows. The PCR reaction mixture $(50 \mu l)$ contained $1 \mu \mathrm{M}$ FP primer, $0.4 \mu \mathrm{M}$ RP1 primer, $0.4 \mu \mathrm{M}$ RP2 primer, $800 \mu \mathrm{M}$ dNTP mix, $10 \mathrm{mM}$ Tris- $\mathrm{HCl}$ (pH 8.3), $50 \mathrm{mM} \mathrm{KCl}, 1.5 \mathrm{mM} \mathrm{MgCl}_{2}, 1 \mathrm{U}$ AmpliTaq Gold DNA polymerase and $3 \mu l$ extracted DNA. PCR consisted of $9 \mathrm{~min}$ at $95^{\circ} \mathrm{C}$ followed by 35 cycles at $94^{\circ} \mathrm{C}$ for $30 \mathrm{sec}, 63^{\circ} \mathrm{C}$ for $30 \mathrm{sec}$ and $72^{\circ} \mathrm{C}$ for $30 \mathrm{sec}$, with a final extension at $72^{\circ} \mathrm{C}$ for $7 \mathrm{~min}$. DNAs from Taiwanese ORFV Nantou, Taiping and Hoping strains [4] were used as the standard strains in the genotyping, and DNA from the

Table 1. Viruses and accession numbers for the sequences

\begin{tabular}{|c|c|c|c|c|c|c|}
\hline \multirow[t]{2}{*}{ Host } & \multirow[t]{2}{*}{ Virus } & & \multirow[t]{2}{*}{ Reference } & \multicolumn{3}{|c|}{ Accession No.* } \\
\hline & & & & Envelope & VEGF & VIR \\
\hline \multirow[t]{10}{*}{ Japanese serow } & Isolate & IJS081 & 22 & AB492240 & AB492084 & AB492085 \\
\hline & & GE & This study & AB493826 & AB436811 & AB499037 \\
\hline & & Aichi & 16,18 & AB521165 & AB436810 & AB522795 \\
\hline & & GHF & 16,18 & AB521166 & AB436809 & AB522796 \\
\hline & & R-1 & 16,18 & AB521167 & AB436808 & AB522797 \\
\hline & & S-1 & $16,19,39$ & AB044796 & AB436807 & AB492086 \\
\hline & Tissue & Kohriyama & 18 & AB521169 & AB522648 & AB522799 \\
\hline & & Suzuran & 18 & AB521171 & AB522649 & AB522800 \\
\hline & & Iwamura & 18 & AB521172 & AB522650 & AB522801 \\
\hline & & Matsumoto & 18 & AB521174 & AB522651 & AB522802 \\
\hline \multirow[t]{3}{*}{ Sheep } & Isolate & HIS & 16,23 & $\mathrm{AB} 189670$ & AB436806 & AB522798 \\
\hline & & Iwate & $16,19,25$ & AB044795 & AB436805 & AB499038 \\
\hline & Tissue & Ena & 18 & AB521175 & AB522652 & AB522803 \\
\hline
\end{tabular}

* VEGF, vascular endothelial growth factor. VIR, viral interferon resistance. 
Table 2. Primers used in this study

\begin{tabular}{|c|c|c|c|}
\hline Primer & Target* & Sequence $\left(5^{\prime}-3^{\prime}\right)^{* *}$ & Reference \\
\hline PPP-1 & Envelope & GTC GTC CAC GAT GAG CAG CT & 17 \\
\hline PPP-4 & & TAC GTG GGA AGC GCC TCG CT & \\
\hline D27F & VEGF & AAT GTA AAT WMT AAC GCC & 16 \\
\hline $11 \mathrm{R}$ & & AAC CCA GAA ACG TCC CGC TAC & \\
\hline $\mathrm{D} 2 \mathrm{R}$ & & CGT TTG GAT MTG CGG TCC & \\
\hline VIR1 & VIR & TTA GAA GCT GAT GCC GCA G & 12 \\
\hline VIR2 & & ACA ATG GCC TGC GAG TG & \\
\hline FP & A32L & GTG TTG ATC ATC GAA GAC TCG GTG & 4 \\
\hline RP1 & & GTC GCC CTT GTC GCC CTT AGT CTC & \\
\hline RP2 & & CCG CCG TCA GAG TCG ACG TCG CCC T & \\
\hline
\end{tabular}

* VEGF, vascular endothelial growth factor. VIR, virus interferon resistance.

** W, A/T. M, A/C.

ORFV NZ2 strain [34] was used as a reference strain. DNA from the Taiwanese ORFV and NZ2 strains were kindly provided by Drs. M. L. Wong (National Chung-Hsing University, Taiwan) and A. A. Mercer (University of Otago, New Zealand), respectively.

\section{RESULTS}

Sequence analyses: A partial nucleotide sequence of the viral envelope gene (554 bp) was the first sequence determined from the PCR product. From the sequence analysis, the newly isolated GE (2007) and IJS081 (2008) strains were classified as ORFVs. This indicates that the recent outbreaks in Japanese serows were caused by ORFV and not by other PPV species, as in the case of the recent reindeer outbreak [42]. The sequences from both the isolated virus and lesions were identical, indicating that this was not a case of isolation of a genetically minor virus from lesions. The GE and IJS081 sequences had no deletions or insertions compared with the published sequences of the S-1 strain, which was isolated in 1985, and compared with sequences from the ORFVs of earlier outbreaks in Japanese serows $[18,19]$. The only difference was a single nucleotide substitution in the GE sequence compared with the S-1 sequence, which had no changes in the coded amino acid (Fig. 2A).

The complete nucleotide sequences of the VEGF and VIR genes were determined to be the same length among all 10 ORFVs that infected Japanese serows, i.e., 137 and 183 amino acids, respectively (Fig. 2B and 2C). The VEGF sequences in the S-1 and IJS081 strains differed by one amino acid substitution, whereas the $\mathrm{S}-1$ and GE sequences were identical; the VEGF sequences of S-1, Aichi, GHF, R1, Suzuran, Iwamura and Ena were also identical. There was one amino acid substitution in the VEGF sequences of the Kohriyama, Matsumoto and Iwate strains, which was at a different position compared with the substitution in the IJS081 sequence. However, in comparison with the S-1 sequence, there were no more than two amino acid substitutions in the VEGF sequences among the ORFVs from Japanese serows and sheep, with the exception of the HIS strain from sheep. The amino acid sequence of HIS VEGF was quite different from the other VEGF sequences; however, eight cysteine residues in the gene were conserved among all of the Japanese ORFVs, including the HIS strain as described previously [16]. These conserved residues are also conserved in all members of the VEGF family, including viral VEGF, human VEGF-A to -D, placenta growth factor 1 and bovine, guinea pig and rat VEGFs [28, 31].

The amino acid sequence of the VIR gene was identical among all 10 ORFVs from Japanese serows and two of the ORFVs from sheep (Fig. 2C), with no nucleotide substitutions. The only differences were in the sequence from the HIS strain from sheep, which contained two amino acid substitutions. The determined nucleotide sequences were submitted to DDBJ/EMBL/GenBank under the accession numbers shown in Table 1.

Genotyping by differential PCR for the A32L gene classified all 13 Japanese ORFVs into the same genotype (Fig. 3 ). The genotype of the Japanese ORFVs is the same as that of the Taiping and NZ2 strains (Fig. 3).

\section{DISCUSSION}

The sequence of the PPV envelope gene, a homologue of vaccinia virus major envelope antigen p37K [38], has been widely used as a molecular target for virus detection and diagnosis of infection $[11,17]$ and for identification of species within the genus Parapoxvirus [3, 19, 41]. Since a large number of sequence data sets have been deposited in DDBJ/ EMBL/GenBank, they can be used for epidemiological and phylogenetic analyses of PPVs. Thus, to characterize the PPVs in recent outbreaks (2007 and 2008) in Japanese serows, we first determined the sequence of the envelope gene.

Previous sequence analyses of the envelope gene revealed that the sequence is highly conserved among Japanese ORFVs $[18,19]$. The amino acid sequences of the newly isolated GE and IJS081 strains were also almost identical to the previously determined sequences, containing only one nucleotide silent mutation in the GE strain. These results suggest that the envelope sequence is highly conserved in ORFVs infecting Japanese serows. However, our results are not consistent with observations in other countries, where sequence variations in the envelope gene of 


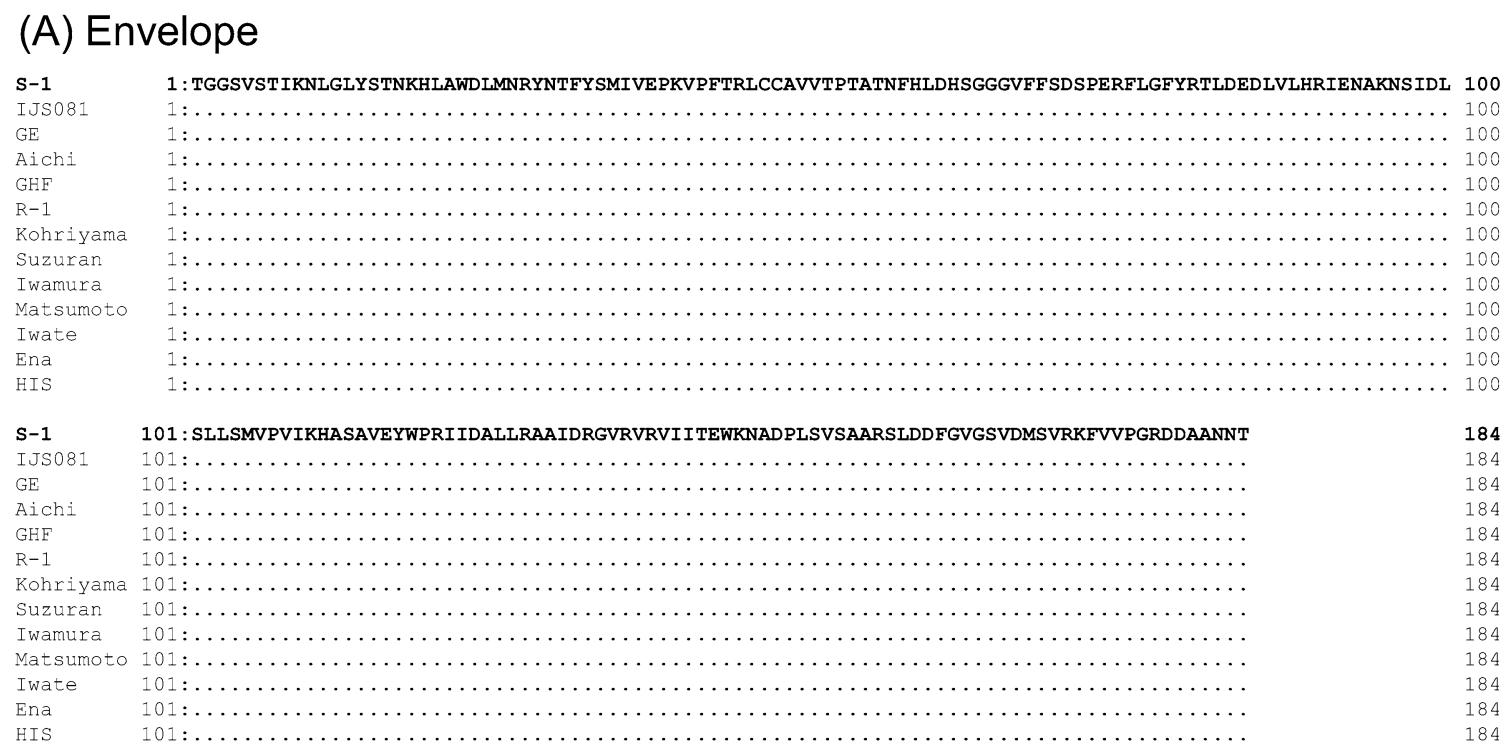

\section{(B) VEGF}

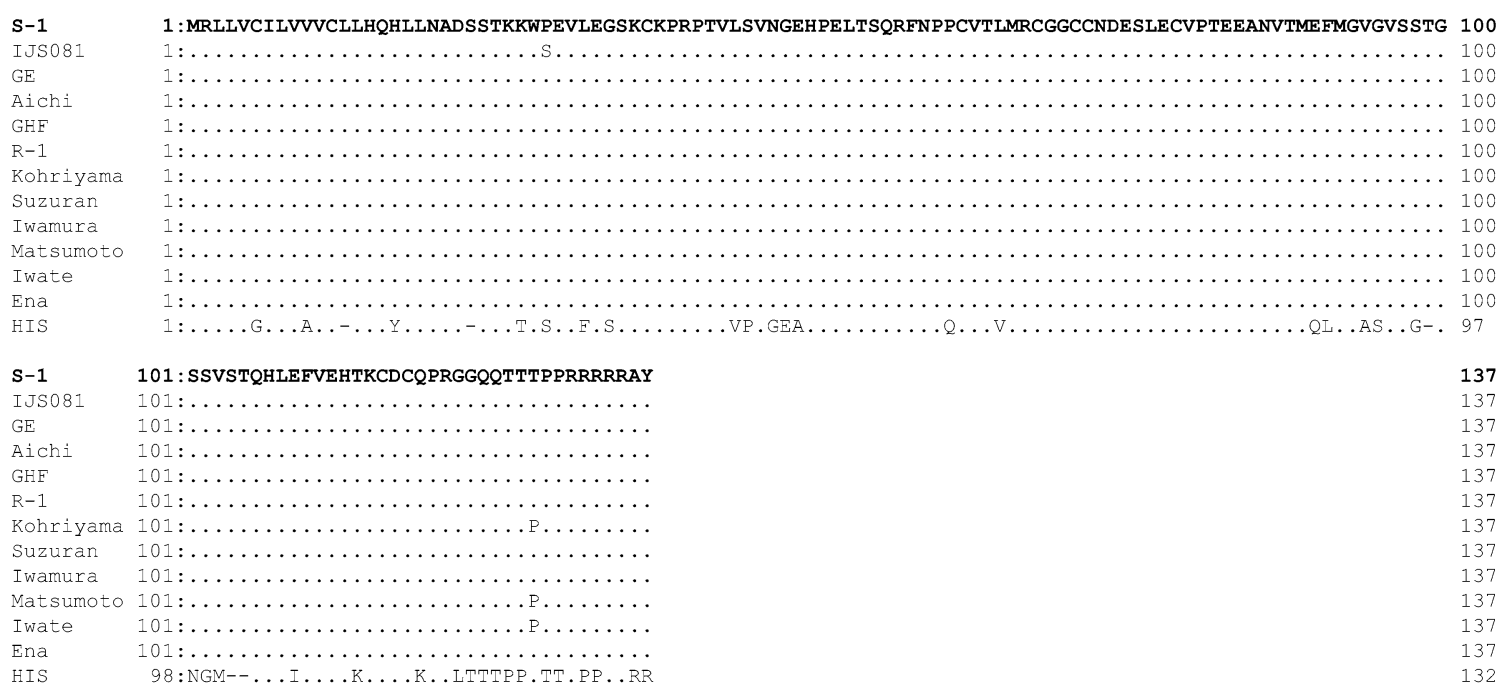

ORFVs from the same outbreak have been reported [1, 5, 6, $12,14,24]$. Guo et al. reported an outbreak of ORFV infection in a zoo, in which a single ORFV likely infected musk ox (Ovibos moschatus), domestic Shetland sheep (Ovis aries) and Sichuan takin (Budorcas taxicolor tibetana), but the amino acid sequence of the viral envelope gene contained one or two substitutions in each animal [12]. These contradictory findings raise the possibility that, although the envelope sequence is suitable for species-identification and phylogenetic analysis of PPVs, it is not suitable for analysis of genetic heterogeneity in Japanese ORFVs. Therefore, we analyzed further gene sequences and genotyped ORFVs using three non-structural protein genes, VEGF, VIR and A32L.

The VEGF and VIR proteins are viral non-structural pro- teins known to be factors involved with virulence and interference of host immune responses [13]. Skin lesions and histopathological changes were relatively reduced in sheep experimentally infected with ORFV lacking functional VEGF $[35,43]$. The VIR gene encodes a dsRNA-binding protein that is involved in inhibition of the antiviral activity of host interferons [29]. Surprisingly, the amino acid sequences of the VEGF and VIR genes of the GE strain were identical to the sequences of the S-1 strain, which was isolated in 1985, and also to the VIR sequence of the Iwate strain, which was isolated in 1970. One amino acid was substituted in the IJS081 VEGF sequence, but the IJS081 VIR sequence is identical to the S-1 and Iwate sequences. Chan et al. similarly observed only a few variations in the envelope and VIR gene sequences in Taiwanese ORFVs 


\section{(C) VIR}

S-1
IJS081
GE
Aichi
GHF
R-1
Kohriyama
Suzuran
Iwamura
Matsumoto
Iwate
Ena
HIS
S-1
IJS081
GE
Aichi
GHF
R-1
Kohriyama
Suzuran
Iwamura
Matsumoto
Iwate
Ena
HIS

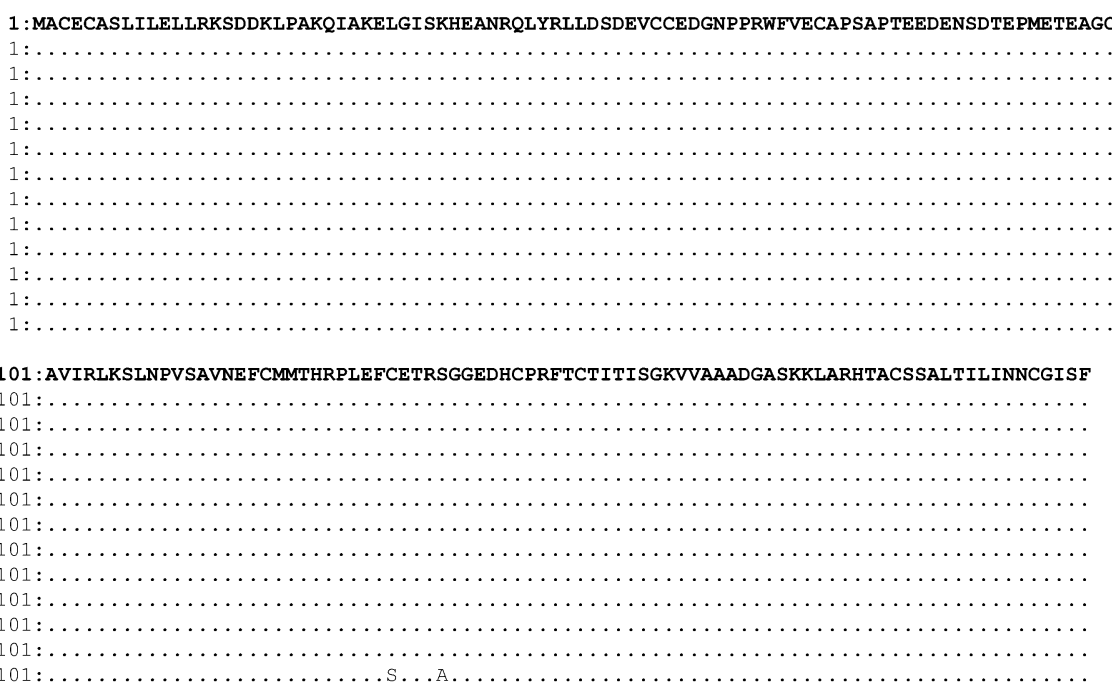

Fig. 2. Alignment of the deduced amino acid sequences. (A) Partial amino acid sequences of the viral envelope gene. (B) Complete amino acid sequences of the VEGF gene. (C) Complete amino acid sequences of the VIR gene.

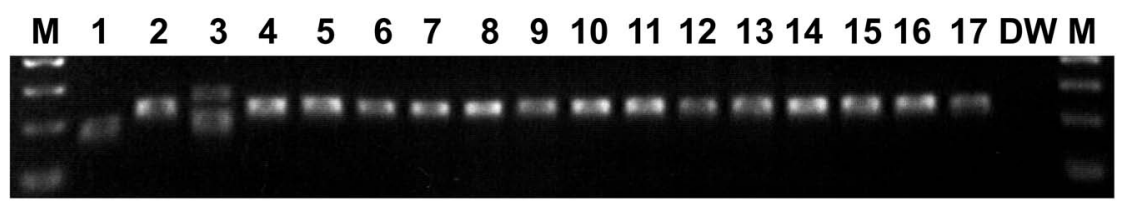

Fig. 3. Genotyping of Japanese ORFVs by differential PCR for the A32L gene. Three standard strains of genotypes showed three different patterns (Lane 1, Nantou, Lane 2, Taiping, and Lane 3, Hoping). All of the Japanese ORFVs (Lanes 5 to 17) were classified into the same genotype with the Taiping (Lane 2) and NZ2 (Lane 4) strains. Lane M, Marker. Lane 4, NZ2 as a reference strain. Lane 5, IJS081. Lane 6, GE. Lane 7, Aichi. Lane 8, GHF. Lane 9, R-1. Lane 10, S-1. Lane 11, Kohriyama. Lane 12, Suzuran. Lane 13, Iwamura. Lane 14, Matsumoto. Lane 15, HIS. Lane 16, Iwate. Lane 17, Ena. Lane DW, distilled water as a negative control.

from goats [4]. All 13 Japanese ORFVs were classified into the same genotype by the differential PCR for the A32L gene. On the other hand, the Taiwanese ORFVs were split into three genotypes by the differential PCR for the A32L gene, indicating sequence variations and deletions in the gene [4], and genome recombination, such as duplication, transposition and deletion, in cultured cells has also been reported [7, 10]. Thus, these results suggest that ORFVs that have a genetic character like the S-1/Iwate strain other than the HIS strain, at least in the envelope, VEGF and VIR genes, are highly adapted and maintained in Japanese serows. These factors may be involved in the adaptation to Japanese serows, namely receptor-usage, interaction with cellular proteins for viral replication and interference with the host immune responses.

In conclusion, comparative genetic analyses revealed that recent outbreaks in Japanese serows are caused by ORFVs that are genetically closely related to the ORFVs found in earlier outbreaks and that these ORFVs have been circulating among Japanese serows over a long period. It is possible that, like cattle with bovine papular stomatitis virus [15, 37], certain Japanese serows are subclinically infected with ORFVs and that relapse of the disease occurs.

ACKNOWLEDGMENT(S). We are grateful to Dr. A. A. Mercer (University of Otago, Dunedin, New Zealand) for providing ORFV NZ2, Dr. N. Minamoto (Formerly Gifu University, Gifu, Japan) for providing ORFV S-1 and the National Institute of Animal Health (Tsukuba, Japan) for providing the other viruses. We also thank Dr. M. L. Wong (National Chung-Hsing, University, Taichung, Taiwan) for providing DNA from the ORFV Nantou, Taiping and Hoping strains. This study was supported in part by a Grant-inAid for Scientific Research from the Ministry of Education, Culture, Sports, Science and Technology, Japan. 


\section{REFERENCES}

1. Abrahao, J. S., Campos, R. K., Trindade, G. S., Guedes, M. I., Lobato, Z. I., Mazur, C., Ferreira, P. C., Bonjardim, C. A. and Kroon, E. G. 2009. Detection and phylogenetic analysis of Orf virus from sheep in Brazil: a case report. Virol. J. 6: 47.

2. Asakawa, Y., Imaizumi, K., Tajima, Y. and Endo, M. 1952. Studies on a contagious ecthyma-like disease observed among the sheep. Jpn. J. Med. Sci. Biol. 5: 475-486.

3. Becher, P., Konig, M., Muller, G., Siebert, U. and Thiel, H. J. 2002. Characterization of sealpox virus, a separate member of the parapoxviruses. Arch. Virol. 147: 1133-1140.

4. Chan, K. W., Hsu, W. L., Wang, C. Y., Yang, C. H., Lin, F. Y., Chulakasian, S. and Wong, M. L. 2009. Differential diagnosis of orf viruses by a single-step PCR. J. Virol. Methods 160: 8589.

5. Chan, K. W., Lin, J. W., Lee, S. H., Liao, C. J., Tsai, M. C., Hsu, W. L., Wong, M. L. and Shih, H. C. 2007. Identification and phylogenetic analysis of orf virus from goats in Taiwan. Virus Genes 35: 705-712.

6. Chan, K. W., Yang, C. H., Lin, J. W., Wang, H. C., Lin, F. Y., Kuo, S. T., Wong, M. L. and Hsu, W. L. 2009. Phylogenetic analysis of parapoxviruses and the C-terminal heterogeneity of viral ATPase proteins. Gene 432: 44-53.

7. Cottone, R., Buttner, M., Bauer, B., Henkel, M., Hettich, E. and Rziha, H. J. 1998. Analysis of genomic rearrangement and subsequent gene deletion of the attenuated Orf virus strain D1701. Virus Res. 56: 53-67.

8. Damon, I. K. 2007. Poxviruses. pp. 2947-2975. In: Fields Virology, 5th ed. (Knipe, D. M. and Howley, P. M. eds.), Lippincott Williams \& Wilkins, Philadelphia.

9. Delhon, G., Tulman, E. R., Afonso, C. L., Lu, Z., de la ConchaBermejillo, A., Lehmkuhl, H. D., Piccone, M. E., Kutish, G. F. and Rock, D. L. 2004. Genomes of the parapoxvirus orf virus and bovine papular stomatitis virus. J. Virol. 78: 168-177.

10. Fleming, S. B., Lyttle, D. J., Sullivan, J. T., Mercer, A. A. and Robinson, A. J. 1995. Genomic analysis of a transpositiondeletion variant of orf virus reveals a $3.3 \mathrm{kbp}$ region of nonessential DNA. J. Gen. Virol. 76: 2969-2978.

11. Gallina, L., Dal Pozzo, F., McInnes, C. J., Cardeti, G., Guercio, A., Battilani, M., Ciulli, S. and Scagliarini, A. 2006. A real time PCR assay for the detection and quantification of orf virus. J. Virol. Methods 134: 140-145.

12. Guo, J., Rasmussen, J., Wunschmann, A. and de La ConchaBermejillo, A. 2004. Genetic characterization of orf viruses isolated from various ruminant species of a zoo. Vet. Microbiol. 99: 81-92.

13. Haig, D. M. and McInnes, C. J. 2002. Immunity and counterimmunity during infection with the parapoxvirus orf virus. Virus Res. 88: 3-16.

14. Hosamani, M., Bhanuprakash, V., Scagliarini, A. and Singh, R. K. 2006. Comparative sequence analysis of major envelope protein gene (B2L) of Indian orf viruses isolated from sheep and goats. Vet. Microbiol. 116: 317-324.

15. Iketani, Y., Inoshima, Y., Asano, A., Murakami, K., Shimizu, S. and Sentsui, H. 2002. Persistent parapoxvirus infection in cattle. Microbiol. Immunol. 46: 285-291.

16. Inoshima, Y. and Ishiguro, N. 2010. Molecular and biological characterization of vascular endothelial growth factor of parapoxviruses isolated from wild Japanese serows (Capricornis crispus). Vet. Microbiol. 140: 63-71.

17. Inoshima, Y., Morooka, A. and Sentsui, H. 2000. Detection and diagnosis of parapoxvirus by the polymerase chain reac- tion. J. Virol. Methods 84: 201-208.

18. Inoshima, Y., Murakami, K., Wu, D. and Sentsui, H. 2002. Characterization of parapoxviruses circulating among wild Japanese serows (Capricornis crispus). Microbiol. Immunol. 46: $583-587$.

19. Inoshima, Y., Murakami, K., Yokoyama, T. and Sentsui, H. 2001. Genetic heterogeneity among parapoxviruses isolated from sheep, cattle and Japanese serows (Capricornis crispus). J. Gen. Virol. 82: 1215-1220.

20. Inoshima, Y., Shimizu, S., Minamoto, N., Hirai, K. and Sentsui, H. 1999. Use of protein AG in an enzyme-linked immunosorbent assay for screening for antibodies against parapoxvirus in wild animals in Japan. Clin. Diagn. Lab. Immunol. 6: 388-391.

21. Inoshima, Y., Yamamoto, Y., Takahashi, T., Shino, M., Katsumi, A., Shimizu, S. and Sentsui, H. 2001. Serological survey of parapoxvirus infection in wild ruminants in Japan in 19969. Epidemiol. Infect. 126: 153-156.

22. Ito, M., Hayakawa, Y., Shintani, E. and Inoshima, Y. 2009. Molecular characterization of parapoxviruses from infected wild Japanese serows (Capricornis crispus) in Ishikawa Prefecture. Jpn. J. Zoo Wildl. Med. 14: 111-114.

23. Kanou, Y., Inoshima, Y., Shibahara, T., Ishikawa, Y., Kadota, K., Ohashi, S., Morioka, K., Yoshida, K. and Yamada, S. 2005. Isolation and characterization of a parapoxvirus from sheep with papular stomatitis. JARQ 39: 197-203.

24. Klein, J. and Tryland, M. 2005. Characterisation of parapoxviruses isolated from Norwegian semi-domesticated reindeer (Rangifer tarandus tarandus). Virol. J. 2: 79.

25. Kumagai, T., Shimizu, M., Ito, Y., Kanno, S., Nakagawa, M., Sato, K., Mukainakano, K. and Ohta, H. 1971. Contagious pustular dermatitis of sheep. Proceeding of the 71st Meeting of the Japanese Society of Veterinary Science.

26. Kumagai, T., Shimizu, M., Ito, Y., Yamamoto, S., Ito, T., Ohyama, S. and Toshibe, M. 1979. Contagious pustular dermatitis of Japanese serows in Akita Prefecture. Proceeding of the 87th Meeting of the Japanese Society of Veterinary Science.

27. Kuroda, Y., Yoshida, M., Shibahara, T., Matsui, T., Nakane, T., Hara, H., Inoshima, Y. and Sentsui, H. 1999. An epidemic of parapoxvirus infection among cattle: isolation and antibody survey. J. Vet. Med. Sci. 61: 749-753.

28. Lyttle, D. J., Fraser, K. M., Fleming, S. B., Mercer, A. A. and Robinson, A. J. 1994. Homologs of vascular endothelial growth factor are encoded by the poxvirus orf virus. J. Virol. 68: 84-92.

29. McInnes, C. J., Wood, A. R. and Mercer, A. A. 1998. Orf virus encodes a homolog of the vaccinia virus interferon-resistance gene E3L. Virus Genes 17: 107-115.

30. Mercer, A. A., Ueda, N., Friederichs, S.-M., Hofmann, K., Fraser, K. M., Bateman, T. and Fleming, S. B. 2006. Comparative analysis of genome sequences of three isolates of Orf virus reveals unexpected sequence variation. Virus Res. 116: 146158.

31. Meyer, M., Clauss, M., Lepple-Wienhues, A., Waltenberger, J., Augustin, H. G., Ziche, M., Lanz, C., Buttner, M., Rziha, H. J. and Dehio, C. 1999. A novel vascular endothelial growth factor encoded by orf virus, VEGF-E, mediates angiogenesis via signalling through VEGFR-2 (KDR) but not VEGFR-1 (Flt-1) receptor tyrosine kinases. EMBO J. 18: 363-374.

32. Morita, C., Izawa, H. and Soekawa, M. 1967. Isolation of a paravaccinia virus from a cow in Japan. Jpn. J. Vet. Sci. 29: 171-175.

33. Robinson, A. J. and Lyttle, D. J. 1992. Parapoxviruses: their 
biology and potential as recombinant vaccines. pp. 285-327. In: Recombinant Poxviruses (Binns, M. and Smith, G. L. eds.), CRC Press, Boca Raton.

34. Robinson, A. J., Ellis, G. and Balassu, T. 1982. The genome of orf virus: restriction endonuclease analysis of viral DNA isolated from lesions of orf in sheep. Arch. Virol. 71: 43-55.

35 Savory, L. J., Stacker, S. A., Fleming, S. B., Niven, B. E. and Mercer, A. A. 2000. Viral vascular endothelial growth factor plays a critical role in orf virus infection. J. Virol. 74: 1069910706.

36. Sentsui, H., Inoshima, Y., Minami, A., Yamamoto, Y., Murakami, K. and Shimizu, S. 2000. Survey on antibody against parapoxvirus among cattle in Japan. Microbiol. Immunol. 44: 73-76.

37. Sentsui, H., Murakami, K., Inoshima, Y., Shibahara, T. and Yokomizo, Y. 1999. Isolation of parapoxvirus from a cow treated with interferon $\gamma$. Vet. Microbiol. 70: 143-152.

38. Sullivan, J. T., Mercer, A. A., Fleming, S. B. and Robinson, A. J. 1994. Identification and characterization of an orf virus homologue of the vaccinia virus gene encoding the major envelope antigen p37K. Virology 202: 968-973.
39. Suzuki, T., Minamoto, N., Sugiyama, M., Kinjo, T., Suzuki, Y., Sugimura, M. and Atoji, Y. 1993. Isolation and antibody prevalence of a parapoxvirus in wild Japanese serows (Capricornis crispus). J. Wildl. Dis. 29: 384-389.

40. Suzuki, Y., Sugimura, M., Atoji, Y., Minamoto, N. and Kinjo, T. 1986. Widespread of parapox infection in wild Japanese serows, Capricornis crispus. Jpn. J. Vet. Sci. 48: 1279-1282.

41. Thomas, K., Tompkins, D. M., Sainsbury, A. W., Wood, A. R., Dalziel, R., Nettleton, P. F. and McInnes, C. J. 2003. A novel poxvirus lethal to red squirrels (Sciurus vulgaris). J. Gen. Virol. 84: 3337-3341.

42. Tikkanen, M. K., McInnes, C. J., Mercer, A. A., Büttner, M., Tuimala, J., Hirvelä-Koski, V., Neuvonen, E. and Huovilainen, A. 2004. Recent isolates of parapoxvirus of Finnish reindeer (Rangifer tarandus tarandus) are closely related to bovine pseudocowpox virus. J. Gen. Virol. 85: 1413-1418.

43. Wise, L. M., Savory, L. J., Dryden, N. H., Whelan, E. M., Fleming, S. B. and Mercer, A. A. 2007. Major amino acid sequence variants of viral vascular endothelial growth factor are functionally equivalent during Orf virus infection of sheep skin. Virus Res. 128: 115-125. 